\title{
Effectiveness of Principals Interpersonal Communication: A Literature Review
}

\author{
Mutiara Nur Ahlaini, Sowiyah, Umigiarini Pangestu and Felia Santika \\ Department Teacher Training and Education, Lampung University, Indonesia
}

\begin{abstract}
The purpose of this review is to determine the effectiveness of interpersonal communication of the principal In context of the world. This research uses compare journals related to the effectiveness of interpersonal communication in the sphere of education. Based on the results of a literature review from various countries in the world, the authors found that interpersonal communication can help the school principal in carrying out their duties by communicating in interpersonal with anyone. Therefore, the principal is expected to communicate well in interpersonal to create relationships, openness and trust within the scope of the organization Communication that can be done by the principal is interpersonal communication to create the relationship and trust are invited to communicate. Interpersonal communication can be effective if communication is conducted face-to-front and two-way with openness, clarity, transparency, brief, kindness, concrete, consideration. The importance of the effectiveness of interpersonal communication in education attracts researcher to examine, and this article is to test how the effectiveness of interpersonal communication of the principal in the organization. With the expectation of the principal can develop continuously interpersonal communication to build relationships and trust to anyone.
\end{abstract}

Keywords: effectiveness, comunication interpersonal, principal

\section{INTRODUCTION}

$\mathrm{C}$ ommunication is $98 \%$ of the most effective and significant of may running function of management and aspects of leadership (Baxter, 2014; Sabanc1, Ahmet Şahin, Sönmez, \& Yılmaz, 2016). Communication plays an important role in the implementation of organizational activities are supported by the rapid development of communication as organizational needs change(Üstüner \& Kis, 2014). Managers' skills and effective leaders can be seen in human relationships, can develop other people and networks, can understand each other in receiving and providing information, positive non-verbal behaviour, encouraging communication up and down, listening effectively, developing strong symbolic messages (Sabanci, Sahin, \& Özdemir, 2016). The leader in carrying out his duties and responsibilities with management functions is primarily communication that can effectively streamline his leadership.

The leader that will be discussed in this paper is the principal. Principals struggle in conducting effective conversations about staff performance issues, tend to tolerate, protect, and work effectively in their resolve (Le Fevre \& Robinson, 2015). Judging from the assessment and monitoring is less effective from the aspect of internal communication, communication that occurs from the principal to the teachers and employees who only in the form of orders to promptly complete the duties of teachers and employees or the delivery of information from the school principal to the teachers and employees is still very difficult due to separate principal and teacher offices and employee offices (Iriono, 2017).

In communication, competent communicators should ideally be able to control and manipulate their environment to achieve personal goals (Lesenciuc dan Codreanu, 2012). Interpersonal communication is believed to effectively lead the leader in carrying out its duties. Interpersonal communication will realize a person in carrying out his duty with a big responsibility to achieve educational objectives and otherwise will have the impact the quality of human resources if communication is not used properly (Syarif, 2011). Interpersonal communication will give a change in leadership behavior (Le Fevre \& Robinson, 2015).

\section{LITERATURE RIVIEW \& METHODS}

The review of this library focuses on the effectiveness of school Interpersonal communication.

Search methods and reviews

The review process starts with a search engine, Google Scholar, to search for articles with keywords"Interpersonal communication effectiveness of school principals". The search was made the boundaries of 2005-2020 and identified a total of more dari200 studies and articles in and out of line with research and that entered into this study. Previous research criteria for inclusion in this study are as follows:

a. Qualitative and quantitative results of .relationship Effectiveness Of Principals Interpersonal Communication

b. Research conducted in the world

c. This study uses English

d. Dissertations and theses excluded

The steps in the Literature Review of each of the variables of the school principal's transformational leadership toward the performance of teachers to improve student achievement include:

Step1: Formulate problems

1. Choose a topic that fits your issues and interests

2. Problems must be written in full and accurate. 
Step 2: Find the literature

1. Find relevant literature with research

2. Get an overview of research topics

3. Research sources are helpful when supported by the knowledge of the topics studied.

4. The source provides an overview or summary of previous research.

Step 3: Evaluate the Data
1. Take a look at any contributions to the topics discussed

2. Search and find the right data source as needed to support research

3. Data can be quantitative data, qualitative data and data derived from the combination of bot

Step 4: Analyze and interpret

1. Discuss and discover and summarize literature.

Table 1: Mean and Standard Deviation of Pretest and Posttest Scores

\begin{tabular}{|c|c|c|c|c|c|}
\hline $\begin{array}{l}\text { Author and } \\
\text { Publication } \\
\text { Year }\end{array}$ & Title & Country & Methods & Sample & Findings \\
\hline Arar (2019) & $\begin{array}{l}\text { Arab Principals' and Teachers' } \\
\text { Perceptions of Trust And } \\
\text { Regulation and Their } \\
\text { Contribution to School } \\
\text { Processes }\end{array}$ & $\begin{array}{l}\text { Arab di } \\
\text { Israel }\end{array}$ & Qualitative & 35 Respondent & $\begin{array}{l}\text { The analysis of the interviewees' accounts yielded three main themes: } \\
\text { perceptions of trust, factors assisting or hindering the formation of } \\
\text { trust in school, and the expressions of trust in schools. } \\
\text { Trust is considered important for successful schools. trust increases in } \\
\text { schools when the principal applies, transparent decision-making } \\
\text { process. This increases the staff's sense of self-effectiveness and their } \\
\text { sense from school } \\
\text { When the principal opens up dialog with the teachers and practices } \\
\text { fair assessment and support for the teachers, providing them with } \\
\text { autonomy for their teaching and participation in the school } \\
\text { organization, a common language is formed and a culture of dialog- } \\
\text { dialogue creates the basis for a supportive, trust-based work } \\
\text { environment }\end{array}$ \\
\hline $\begin{array}{l}\text { Bambacas } \\
\text { and } \\
\text { Patrickson } \\
(2008)\end{array}$ & $\begin{array}{l}\text { Interpersonal communication } \\
\text { skills that enhance } \\
\text { organisational commitment }\end{array}$ & $\begin{array}{l}\text { Indonesia } \\
\text { Australia } \\
\text { Selatan }\end{array}$ & Qualitative & $\begin{array}{l}32 \mathrm{HR} \\
\text { managers and } \\
100 \text { or more } \\
\text { employees }\end{array}$ & $\begin{array}{l}\text { Senior HR managers expect managers to be effective interpersonal } \\
\text { communication that focuses primarily on the clarity and frequency of } \\
\text { messages, their ability to actively listen to and the ability to lead in a } \\
\text { collaborative manner. The way messages are sent, especially their } \\
\text { clarity, and the leadership style that generates trust, is most important } \\
\text { when HR managers want to increase employee commitment to the } \\
\text { organization. However, this skill is also found less }\end{array}$ \\
\hline $\begin{array}{l}\text { Baxter } \\
(2013)\end{array}$ & $\begin{array}{l}\text { An independent inspectorate? } \\
\text { Addressing the paradoxes of } \\
\text { educational inspection in } 2013\end{array}$ & Inggris & Qualitative & ------- & $\begin{array}{l}\text { Ofsted is in a difficult position and in this paper I have argued that the } \\
2012 \text { Inspection Framework and its associated re-modelling of the } \\
\text { workforce, in seeking to address previous criticisms and in attempting } \\
\text { to bring an ostensibly more developmental culture to inspection, have } \\
\text { created a paradoxical system which presents a substantial threat to its } \\
\text { continued existence as a credible regulatory body and legitimate tool } \\
\text { by which to effect the governing of education in England. }\end{array}$ \\
\hline $\begin{array}{l}\text { Cohen } \\
(2019)\end{array}$ & $\begin{array}{l}\text { Principals' leadership } \\
\text { behaviours that shaped teachers' } \\
\text { motivation to implement } \\
\text { educational ICT reform imposed } \\
\text { by state authorities in Israel }\end{array}$ & Tivon, Israel & Qualitative & $\begin{array}{l}5 \text { Kepsek dan } \\
35 \text { guru }\end{array}$ & $\begin{array}{l}\text { Results revealed that the difference in the headmaster's attitude toward } \\
\text { filing changes influenced the way they introduced it to school staff. } \\
\text { The principal enthusiasm led to the teacher's active involvement in } \\
\text { process changes. The principal supporting the proposed change at the } \\
\text { beginning of the implementation are those who can recognize the } \\
\text { relationship between the reform vision, local school needs and core } \\
\text { values. Previous studies in the world and in Israel show that principals } \\
\text { often experience gaps between school needs, processes occurring in } \\
\text { schools based on local initiatives and state reform standards }\end{array}$ \\
\hline $\begin{array}{l}\text { Iriono } \\
(2017)\end{array}$ & $\begin{array}{l}\text { Hubungan Antara Komunikasi } \\
\text { Interpersonal Kepala Sekolah } \\
\text { dengan Kinerja Guru Di Sma } \\
\text { Swasta Uisu Medan } \\
\text { Relationship between school's } \\
\text { Interpersonal communication } \\
\text { with teacher performance } \\
\text { at Uisu Medan Private High } \\
\text { School. }\end{array}$ & Indonesia & Quantitative & $\begin{array}{l}29 \text { Orang } \\
\text { guru }\end{array}$ & $\begin{array}{l}\text { Research suggests that between interpersonal communication } \\
\text { principal with the performance of private high school } \\
\text { teachers UISU Medan has a positive and significant relationship. It is } \\
\text { shown from the magnitude value of } \overline{\text { agt; }}=3.09 \text { gat } \\
\text { While the correlation coefficient of Rcount }=0.5121 \text { \&gt; Rtabel }= \\
0.367 \text {. The influence of the school principal's interpersonal } \\
\text { communication variables on the teacher's performance was } 26.23 \% \text {. }\end{array}$ \\
\hline
\end{tabular}




\begin{tabular}{|c|c|c|c|c|c|}
\hline Kwan (2012) & $\begin{array}{l}\text { Assessing school principal } \\
\text { candidates: perspectives of the } \\
\text { hiring superintendents }\end{array}$ & Hongkong & Quantitative & 93 supervisors & $\begin{array}{l}\text { Four criteria were used to assess the principal's position of school } \\
\text { applicants from high school by a Hong Kong school supervisor. This, } \\
\text { in order of importance: a generic managerial; A communication and } \\
\text { presentation; Knowledge and experience; and supplying religious } \\
\text { values. Of these four criteria, only knowledge and experience is } \\
\text { directly related to teaching and learning and is also the only criterion } \\
\text { that can be assessed more objectively. }\end{array}$ \\
\hline $\begin{array}{l}\text { Le Fevre } 1 \\
\text { and } \\
\text { Robinson } \\
(2015)\end{array}$ & $\begin{array}{l}\text { The Interpersonal Challenges Of } \\
\text { Instructional Leadership: } \\
\text { Principals' Effectiveness In } \\
\text { Conversations About } \\
\text { Performance Issues }\end{array}$ & $\begin{array}{l}\text { Selandia } \\
\text { baru }\end{array}$ & $\begin{array}{l}\text { Quantitative } \\
\text { and } \\
\text { Qualitative }\end{array}$ & 27 Principals & $\begin{array}{l}\text { Overall, the principal showed a low to moderate skill level across } \\
\text { Indonesia two conversations. Typically, principals are more skilled in } \\
\text { advocating they } \\
\text { themselves positions rather than deeply investigating and examining } \\
\text { their understanding of the views of parents or teachers }\end{array}$ \\
\hline $\begin{array}{l}\text { Lunenburg } \\
\text { (2010) }\end{array}$ & $\begin{array}{l}\text { The Principal And The School: } \\
\text { What Do Principals Do? }\end{array}$ & Indonesia & Qualitative & $\begin{array}{l}248 \\
\text { administrator }\end{array}$ & $\begin{array}{l}\text { These functions and roles, the headmaster requires three conceptual, } \\
\text { human, and technical skills. Conceptual skills are more important at } \\
\text { the top of the school district hierarchy; Important human skills at all } \\
\text { levels; and technical skills are more important for first-line } \\
\text { supervisors, such as department heads and team leaders. An effective } \\
\text { principal study reveals that the main reason for the principal's failure } \\
\text { is the inability to deal with people. Effective principals are involved in } \\
\text { two categories of task dimensions. One category includes managerial } \\
\text { tasks that are usually associated with the principal's role and enforce } \\
\text { policies, rules, and procedures, and authority relations. The other } \\
\text { categories, called link waking cultures, include setting behavioural } \\
\text { norms, using symbols, institutionalized rituals, and storytelling } \\
\text { designed to build a culture of the foundation of school Excellence. } \\
\text { Superior principals also have excellent people skills. The difference } \\
\text { between effective and successful principals is also examined. }\end{array}$ \\
\hline $\begin{array}{l}\text { Mhaidli, et.al } \\
\text { (2020) }\end{array}$ & $\begin{array}{l}\text { Listen Only When Spoken To: } \\
\text { Interpersonal Communication } \\
\text { Cues as Smart Speaker Privacy } \\
\text { Controls }\end{array}$ & Australia & Mix Method & ----- & $\begin{array}{l}\text { Privacy controls based on practical gesture interpersonal } \\
\text { communication, do not ruin the speaker's intelligent functionality, and } \\
\text { can be easily used by users to choose mute the microphone. Based on } \\
\text { our findings, we discuss insights about the use of interpersonal cues as } \\
\text { a privacy control for smart speakers and other IOT devices. }\end{array}$ \\
\hline $\begin{array}{l}\text { Odhiambo } \\
\text { and Hii } \\
\text { (2012) }\end{array}$ & $\begin{array}{l}\text { Key Stakeholders' Perceptions } \\
\text { of Effective School Leadership }\end{array}$ & Australia & Qualitative & $\begin{array}{l}\text { One Principal } \\
\text { Women, } \\
\text { deputy } \\
\text { headmaster, } \\
60 \text { teachers } \\
\text { and a number } \\
\text { of specialists } \\
\text { and support } \\
\text { staff }\end{array}$ & $\begin{array}{l}\text { Highlighting the way that key stakeholders view quality school } \\
\text { leadership. These are: (1) The principal uses administrative power } \\
\text { (administration); (2) The responsibility of the principal to ensure } \\
\text { quality teaching and learning (instructional leadership); (3) Relational } \\
\text { leadership as a repentant thing for a strong school community (internal } \\
\text { and external relations); (4) Challenging nature of leadership schools; } \\
\text { and (5) The role of the principal in religious leadership and } \\
\text { organizational management. }\end{array}$ \\
\hline $\begin{array}{l}\text { Sabanci; } \\
\text {,et.al (2016) }\end{array}$ & $\begin{array}{l}\text { The Correlation Between } \\
\text { School Managers' } \\
\text { Communication Skills and } \\
\text { School Culture }\end{array}$ & $\begin{array}{l}\text { Antalya, } \\
\text { Turki }\end{array}$ & Qualitative & 372 sampel & $\begin{array}{l}\text { Interpersonal communication skills from school managers and } \\
\text { organizational cultures are medium-correlated. } \\
\text { First analysis, emphatic sensitivity, reflective listening, and creating } \\
\text { positive communication variables together predict a power culture } \\
\text { significantly. Secondly, the final analysis demonstrates emphatic } \\
\text { sensitivity, reflective listening and creates positive communication } \\
\text { variables alongside predicting a significant role culture. Thirdly, the } \\
\text { model demonstrates emphatic sensitivity, reflective listening, and } \\
\text { creates positive communication variables together predicting a } \\
\text { significantly successful culture. }\end{array}$ \\
\hline $\begin{array}{l}\text { Sabanci, } \\
\text { Şahin, and } \\
\text { Özdemir } \\
\text { (2016) }\end{array}$ & $\begin{array}{l}\text { Interpersonal Communication } \\
\text { Skills of the Leaders of } \\
\text { Inspection Groups in Turkey }\end{array}$ & Turkey & Quantitative & 266 Sampel & $\begin{array}{l}\text { Group leaders have high-performance interpersonal communication } \\
\text { skills. The Agreement on communication skills is crucial which is } \\
\text { likely to be a positive proof of climate communication between } \\
\text { leaders and inspectors in the inspection group. }\end{array}$ \\
\hline $\begin{array}{l}\text { Sahenk } \\
(2010)\end{array}$ & $\begin{array}{l}\text { Characteristics of the } \\
\text { headmasters, teachers and } \\
\text { students in an effective school }\end{array}$ & Turki & $\begin{array}{l}\text { Literature } \\
\text { review }\end{array}$ & ------- & $\begin{array}{l}\text { Emphasis is made on the existence of strong communication between } \\
\text { peers, manifesting cognitive, social development, psycho-motor and } \\
\text { kinetic students and the utilization of Academic technology and new } \\
\text { methods of teaching. }\end{array}$ \\
\hline $\begin{array}{l}\text { Sezgin and } \\
\text { Er }(2016)\end{array}$ & $\begin{array}{l}\text { Teacher Perception On School } \\
\text { Principal Communication: A } \\
\text { Qualitative Study Of A Turkish } \\
\text { Primary School }\end{array}$ & $\begin{array}{l}\text { Ankara, } \\
\text { Turki }\end{array}$ & Qualitative & 14 teachers & $\begin{array}{l}\text { Interpersonal communication skills build clear, meaningful and two- } \\
\text { way communication with the teacher. Such skills' development might } \\
\text { also include establishing open communication between the principal } \\
\text { and school stakeholders. It is clear from this study that the teacher's } \\
\text { expectations of good interpersonal communication with the principal }\end{array}$ \\
\hline
\end{tabular}




\begin{tabular}{|c|c|c|c|c|c|}
\hline & & & & & can vary. \\
\hline $\begin{array}{l}\text { Shoho and } \\
\text { Barnett } \\
(2010)\end{array}$ & $\begin{array}{l}\text { The Realities of New Principals: } \\
\text { Challenges, Joys, and Sorrows }\end{array}$ & Amerika & Qualitative & 62 Principals & $\begin{array}{l}\text { the principals has become far too complex to rely solely on } \\
\text { fragmented approaches for preparing current and future school leaders } \\
\text { to deal with the complexities of the job. challenges experienced by } \\
\text { new principals pertain to instructional leadership; managerial issues } \\
\text { such as budgeting and human resources; and community issues } \\
\text { involving climate, politics, and differing expectations from parents. }\end{array}$ \\
\hline Syarif (2011) & $\begin{array}{l}\text { Pengaruh Komunikasi } \\
\text { Interpersonal dan Supervisi } \\
\text { Kepala Sekolah terhadap } \\
\text { Kinerja Guru } \\
\text { (The Effect of Interpersonal } \\
\text { Communication and Principal } \\
\text { Supervision on Teacher } \\
\text { Performance) }\end{array}$ & Indonesia & Qualitative & -------- & $\begin{array}{l}\text { Parse teacher performance which is influenced by interpersonal } \\
\text { communication and supervision by the principal. These two things } \\
\text { have a big influence on teacher performance. }\end{array}$ \\
\hline $\begin{array}{l}\text { Tschannen- } \\
\text { Moran; } \\
\text { DiPaola and } \\
\text { Forsyth } \\
\text { (2011) }\end{array}$ & $\begin{array}{l}\text { In search of trust: Contributing } \\
\text { to the understanding of a taken- } \\
\text { for-granted construct }\end{array}$ & Columbus & Quantitative & & $\begin{array}{l}\text { Trust is increasingly recognized as an important element in high- } \\
\text { functioning schools. The research reported here reported the } \\
\text { development of a strong definition of trust and measures to assess the } \\
\text { primary faculties and beliefs in key stakeholders in their school } \\
\text { community. The study reviewed link trust to school effectiveness, } \\
\text { collaboration, collective efficacy, organizational citizenship, and } \\
\text { teacher professionalism. Cultivating Trust has been linked to } \\
\text { authenticity, collegial and consideration of behavior, as well as } \\
\text { adopting a strength-based approach to school reform furthermore the } \\
\text { student and teacher Trust has been associated with achievement and } \\
\text { identification with the school. }\end{array}$ \\
\hline Umar (2019) & $\begin{array}{l}\text { Conceptualizing the Influence } \\
\text { of Principals' Competence on } \\
\text { Skill Acquisition in Agricultural } \\
\text { Science Subject in Secondary } \\
\text { Schools }\end{array}$ & Nigeria & $\begin{array}{l}\text { Literatur } \\
\text { Review }\end{array}$ & $\begin{array}{l}\text { Articles } 2010 \\
\text { to } 2018\end{array}$ & $\begin{array}{l}\text { Influence of selected factors of the principal's competence on student } \\
\text { acquisition skills in agricultural science subjects. This explains how } \\
\text { these predictions can be improved skill acquisition. }\end{array}$ \\
\hline $\begin{array}{l}\text { Üstüner, and } \\
\text { Kiş (2014) }\end{array}$ & $\begin{array}{l}\text { The Relationship between } \\
\text { Communication Competence } \\
\text { and Organizational Conflict: A } \\
\text { Study on Heads of Educational } \\
\text { Supervisors }\end{array}$ & $\begin{array}{l}\text { Indonesia } \\
\text { Turki }\end{array}$ & $\begin{array}{l}\text { Penelitian } \\
\text { Asosiasi }\end{array}$ & $\begin{array}{l}217 \\
\text { Supervisor }\end{array}$ & $\begin{array}{l}\text { Head of education most supervisors demonstrate communication } \\
\text { competencies including empathy components, social relaxation and } \\
\text { supporting behaviors. Education supervisors also stated that they } \\
\text { sometimes experienced organizational conflicts including intergroup } \\
\text { components, between groups and personal conflicts in their head } \\
\text { departments. A negative level correlation is being found between } \\
\text { competency level communication and organizational conflict of } \\
\text { supervisory head education. }\end{array}$ \\
\hline
\end{tabular}

\section{DISCUSSION OF FINDINGS}

This section reports the key findings reviewed from some articles that the author has read. The analysis showed that most articles focus on how the school's interpersonal communication is effective in the sustainability of an educational organization. The articles that have been reviewed are research conducted in the world. Based on the articles that are reviewed, there are various ways of data collection related to the effectiveness of interpersonal communication, the school principal and the effectiveness of interpersonal communication of the principal. The most commonly used method is using quantitative and qualitative methods.

The research on the effectiveness of interpersonal communication of school principals has been conducted in various countries. Table 1 shows that research has been conducted in educational institutions. The results of most research show that the headmaster in conducting interpersonal communication effectively so it affects the Sustainability of the Organization.
Communication will be effective when the principal knows how to communicate, and understands how important formal and informal communication is, for example: when the meeting; Conversations made by individuals with parents, teachers, and students; Receive and share information about phone calls and email messages with different groups of stakeholders (F. C. Lunenburg, 2010). The Arab education System sees communication to build trust for all stakeholders and education leaders (Arar, 2019). Positive communication, and openness between the headmaster and teachers enables full collaboration and transparency created from the trust in the Organization (Tschannen-Moran, Dipaola, \& Forsyth, 2011).

At the assessment of Hongkong ESR communication Skills School Head is considered to be increasingly important (Kwan, 2012). In this paper will discuss interpersonal communication skills concentrated primarily on the dimension of empathy, understanding, active listening, feedback, effectiveness (openness, clarity, transparency, brief, kindness, concrete, consideration), persuasion, trusting and becoming 
effective senders that are effective body language, verbal effectiveness and non-verbal communication (Sabanci et al., 2016).

The Principal began to focus on the importance of having strong communication skills, not just words but their ongoing actions. Their interpersonal communication skills are constantly being tested in communicating their parents' complaints to teachers (Le Fevre \& Robinson, 2015). Some principals in Israel conduct private and individual communication with teachers to encourage teachers accustomed to implementing changes to be enforced by listening, providing support and support feedback (Cohen, 2019).

In the effectiveness of interpersonal communication, principal need to develop their interpersonal communication skills. The headmaster develops interpersonal communication by establishing clear, meaningful and two-way communication with the teachers and stakeholders of the school (Sezgin \& Er, 2016)Interpersonal communication will be effective when the headmaster performs effectiveness (openness, clarity, transparency, brief, kindness, concrete, consideration) in an organization. Besides supervisors as well as leader groups they think that group leaders have high performance interpersonal communication skills. Groups of leaders report that they perform better in listening to the emphatic, effectiveness, feedback and dimension of mutual trust compared to the view of the inspector (Sabanci et al.,2016) The time of the school principal from 70 to $80 \%$ is spent in interpersonal communication with various stakeholders (Green, 2010; F. C. Lunenburg, \& Irby, B. J, 2006; Matthews, 2010; Sergiovanni, 2009; Tareilo, 2011; Ubben, 2010). According to (Shoho \& Barnett, 2010) Interpersonal communication can help the school principal in carrying out their duties by communicating in interpersonal with anyone. Principals often focus on the importance of having strong communication skills, one of which is that interpersonal communication skills are constantly being tested in dealing with conflicts with teachers, staff, and parents. The effectiveness of interpersonal communication, the principal indicates that there is the interpersonal relationship between the headmaster and the person who is invited (supervisor, teacher, staff or student). The headmaster is regarded as a leader with adequate communication skills to create an effective interpersonal communication network in the school community. In accordance with the results of interpersonal communication research is one of the things that the principal should be aware of in creating a trust relationship between the community (Arar, 2019).

Therefore, the principal is expected to communicate well in an interpersonal way, thus creating relationships, openness and trust within the scope of the organization. Communication that can be done by the principal is interpersonal communication to create the relationship and trust that is invited to communicate (Sabanci et al., 2016; Tschannen-Moran et al., 2011). Interpersonal communication can be effective when communication is conducted face-to-front and two-way with openness, clarity, transparency, brief, kindness, concrete, consideration. With the expectation that the headmaster can continuously develop its interpersonal communication skills so that it can build relationships, trust the participation of organizations in implementing the policies to be applied (Sabanci et al., 2016; Şahenk, 2010; Sezgin \& Er, 2016).

The findings of this study cannot be generalized. The future of studies can focus on how various stakeholders define effective interpersonal communication skills. Therefore, researchers can offer an alternative perspective of the effectiveness of the interpersonal communication skills of the principal, which is pointless to enrich the discussion surrounding the communication quality of the principal. Furthermore, given its small size and qualitative properties of this study, may not be transferred to other contexts. Thus, the future of research can examine the characteristics of effective interpersonal communication skills in large-scale studies. In addition, an international study is needed to compare how effective the interpersonal communication skills of the head of the school are based in different educational systems around the world.

Its broad conclusion is that when the author considers all reviews of the studies on the effectiveness of interpersonal communication, school principals conducted in various countries in the world, indicating that the effectiveness of interpersonal communication is crucial for an organization, including educational and interpersonal communication institutions, having a positive and negative impact on the sustainability of the organization. As with any research, this review has its limitations. First, the articles are reviewed only in English so that other studies are not reviewed due to limitations. Secondly, the scope of the articles being reviewed is still very limited, in Indonesia the existing articles only include on interpersonal communication the headmaster in influencing, related to other factors,

Despite the limited literature we must acknowledge, our findings are expected to contribute to information as the importance of school principal communication for the sustainability of the organization by looking at previous research in the context of the world. In addition, it can help to develop the knowledge of the school principal in communicating interpersonal so that the system exists in the organization effectively and efficiently. Thus, it can broaden our view all in developing interpersonal communication skills. The leader is expected to conduct interpersonal communication so that create interpersonal relationships with the members of the organization. What has not been done in this review literature is expected that researchers can further develop interpersonal communication coverage that corresponds to the development of his day? Because the theme and discussion of communication can always develop, so it is hoped that there will always be research on interpersonal communication in the context of education and the world to provide an understanding in the effectiveness of interpersonal communication. 


\section{REFERENCES}

[1] Adrian Lesenciuc, Aura Codreanu. "Interpersonal Communication Competence: Cultural Underpinnings". Journal of Defense Resources Management (JoDRM) 1:127-138

[2] Arar, K. (2019). Arab principals' and teachers' perceptions of trust and regulation and their contribution to school processes. Leadership and Policy in Schools, 18(4), 648-663. doi:https://doi.org/10.1080/15700763.2018.1475576

[3] Baxter, J . A. (2014). An independent inspectorate? Addressing the paradoxes of educational inspection in 2013. School Leadership \& Management, 34(1), 21-38.

[4] G. (2019). Principals' leadership behaviours that shaped teachers' motivation to implement an educational ICT reform imposed by state authorities in Israel. Israel Affairs, 25(3), 554-570. doi:https://doi.org/10.1080/13537121.2019.1593658

[5] Green, R. L. (2010). The four dimensions of principal leadership: A framework for leading 21st century schools. Boston, MA: Pearson.

[6] Iriono, L. (2017). Hubungan Antara Komunikasi Interpersonal Kepala Sekolahdengan Kinerja Guru Di Sma Swasta Uisu Medan. Benchmarking, 1(1).

[7] Kwan, P. (2012). Assessing school principal candidates: Perspectives of the hiring superintendents. International Journal of Leadership in Education, 15(3), 331-349. doi:http://dx.doi.org/10.1080/13603124.2011.617838

[8] Le Fevre, D. M., \& Robinson, V. M. (2015). The Interpersonal Challenges Of Instructional Leadership: Principals' Effectiveness In Conversations About Performance Issues. Educational administration quarterly, 51(1), 58-95. doi:10.1177 / $0013161 X 13518218$

[9] Lunenburg, F. C. (2010). Communication: The process, barriers, and improving effectiveness. Schooling, 1(1), 1-10.

[10] Lunenburg, F. C., \& Irby, B. J. (2006). The principalship: Vision to action. Belmont,CA: Wadsworth/Cengage.

[11] Matthews, L. J., \& G. M. Crow. (2010). The principalship: New roles in a professional learning community. Boston, MA: Pearson.
[12] Sabanc1, A., Ahmet Sahin, A., Sönmez, M. A., \& Yılmaz, O. (2016). The Correlation Between School Managers' Communication Skills and School Culture. International Journal of Progressive Education, 12(3).

[13] Sabanci, A., Sahin, A., \& Özdemir, İ. (2016). Interpersonal Communication Skills of the Leaders of Inspection Groups in Turkey. Online Submission, 5(4), 148-159. doi:http://dx.doi.org/10.6007/JJARPED/v5-i4/2473

[14] Şahenk, S. S. (2010). Characteristics of the headmasters, teachers and students in an effective school. Procedia-Social and Behavioral Sciences, 2(2), 4298-4304.

[15] Sergiovanni, T. J. (2009). The principalship: A reflective practice perspective. Boson, MA: Pearson.

[16] Sezgin, F., \& Er, E. (2016). Teacher perception of school principal interpersonal communication style: A qualitative study of a Turkish primary school. International Online Journal of Educational Sciences, 8(4). doi:http://dx.doi.org/10.15345/iojes.2016.04.002

[17] Shoho, A. R., \& Barnett, B. G. (2010). The realities of new principals: Challenges, joys, and sorrows. Journal of School leadership, 20(5), 561-596.

[18] Syarif, H. M. (2011). Pengaruh Komunikasi Interpersonal dan Supervisi Kepala Sekolah terhadap Kinerja Guru. Media Akademika, 26(1), 125-137.

[19] Tareilo, J. (2011). Other side of the desk: A 20/20 look at the principalship. Lanham, MD: Rowman \& Littlefield.

[20] Tschannen-Moran, M., Dipaola, M., \& Forsyth, P. (2011). In search of trust: Contributing to the understanding of a taken-forgranted construct. Leading research in educational administration: A Festschrift for Wayne K. Hoy, 1-16.

[21] Ubben, G. C., Hughes, L. W., \& Norris, C. J. (2010). The principal: Creative leadership for excellence in schools (7th ed.). Boston, MA: Pearson.

[22] Üstüner, M., \& Kis, A. (2014). The Relationship between Communication Competence and Organizational Conflict: A Study on Heads of Educational Supervisors. Eurasian Journal of Educational Research, $23-44$ doi:http://dx.doi.org/10.14689/ejer.2014.56.5 